
for Biofuels

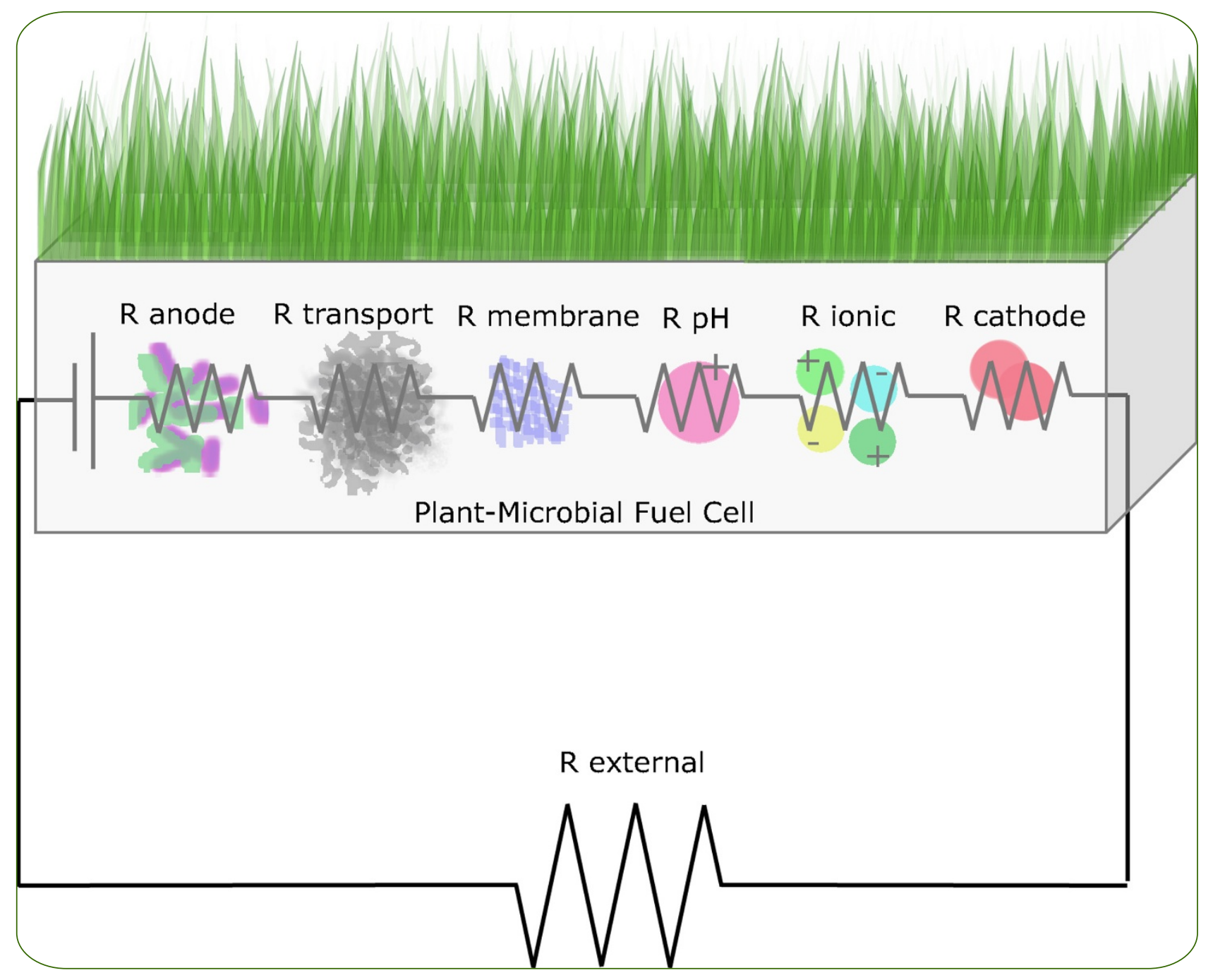

\title{
The flat-plate plant-microbial fuel cell: the effect of a new design on internal resistances
}

Helder et al. 


\title{
The flat-plate plant-microbial fuel cell: the effect of a new design on internal resistances
}

\author{
Marjolein Helder ${ }^{1}$, David PBTB Strik ${ }^{1 *}$, Hubertus VM Hamelers² and Cees JN Buisman ${ }^{1,2}$
}

\begin{abstract}
Due to a growing world population and increasing welfare, energy demand worldwide is increasing. To meet the increasing energy demand in a sustainable way, new technologies are needed. The Plant-Microbial Fuel Cell (P-MFC) is a technology that could produce sustainable bio-electricity and help meeting the increasing energy demand. Power output of the P-MFC, however, needs to be increased to make it attractive as a renewable and sustainable energy source. To increase power output of the P-MFC internal resistances need to be reduced. With a flat-plate P-MFC design we tried to minimize internal resistances compared to the previously used tubular P-MFC design. With the flat-plate design current and power density per geometric planting area were increased (from 0.15 $\mathrm{A} / \mathrm{m}^{2}$ to $1.6 \mathrm{~A} / \mathrm{m}^{2}$ and from $0.22 \mathrm{~W} / \mathrm{m}^{2}$ to and $0.44 \mathrm{~W} / \mathrm{m}^{2}$ ) as were current and power output per volume (from 7.5 $\mathrm{A} / \mathrm{m}^{3}$ to $122 \mathrm{~A} / \mathrm{m}^{3}$ and from $1.3 \mathrm{~W} / \mathrm{m}^{3}$ to $5.8 \mathrm{~W} / \mathrm{m}^{3}$ ). Internal resistances times volume were decreased, even though internal resistances times membrane surface area were not. Since the membrane in the flat-plate design is placed vertically, membrane surface area per geometric planting area is increased, which allows for lower internal resistances times volume while not decreasing internal resistances times membrane surface area. Anode was split into three different sections on different depths of the system, allowing to calculate internal resistances on different depths. Most electricity was produced where internal resistances were lowest and where most roots were present; in the top section of the system. By measuring electricity production on different depths in the system, electricity production could be linked to root growth. This link offers opportunities for material-reduction in new designs. Concurrent reduction in material use and increase in power output brings the P-MFC a step closer to usable energy density and economic feasibility.
\end{abstract}

Keywords: Plant-microbial fuel cell, Design, Flat-plate, Internal resistance, Root growth, Spartina anglica, Sustainable electricity

\section{Background}

With a growing world population and increasing welfare, energy demand worldwide is increasing [1]. Currently used fossil fuels are unevenly distributed over the world, are being depleted, and are unsustainable [2,3]. Sustainable alternative energy sources that are available nowadays all have their drawbacks. They are weather dependent (wind, solar power), compete with food/feed production (some biofuels) [3,4] or involve high investment costs [5]. The Plant-Microbial Fuel Cell (P-MFC) is a technology that can potentially be used weatherindependent, at any place in the world where plants can

\footnotetext{
* Correspondence: david.strik@wur.nl

'Wageningen University - Sub-department of environmental technology, PO box 17, Wageningen $6700 \mathrm{AA}$, The Netherlands

Full list of author information is available at the end of the article
}

grow, without competition with food or feed production, and with relatively low investment costs [6-11]. The technology is still in its infancy, however, and large improvements should be achieved to make this technology energetically and economically feasible. One of the main challenges with current state of technology is its power output. Even though theoretical power output is estimated at $3.2 \mathrm{~W} / \mathrm{m}^{2}$ geometric planting area [10], maximum power output has been improved only from $65 \mathrm{~mW} / \mathrm{m}^{2}$ in 2008 [12] to $220 \mathrm{~mW} / \mathrm{m}^{2}$ in 2010 [9] in systems with plants as sole organic matter source. Current biomass-electricity systems, like anaerobic digestion, produce the same amount of electricity per geometric planting area as the maximum that was achieved in P-MFCs, $220 \mathrm{~mW} / \mathrm{m}^{2}$ [10]. So even at current power output, the P-MFC could compete with anaerobic

\section{Biomed Central}


digestion based on electricity production per geometric planting area. But maximum power outputs of the P-MFCs have been achieved in short term tests like polarization curves and were not sustained for longer periods of time. Over longer periods of time, average power output is limited to maximally $50 \mathrm{~mW} / \mathrm{m}^{2}$ geometric planting area [11]. In some experiments a decrease in power output during runtime of an experiment was observed,due to an increase of membrane resistance and build-up of ion-transport resistances [11]. In one recent publication, however, it is shown that average power output increases with runtime of the experiment. This latter experiment was done with a flat-plate PMFC [13].

Power density of a P-MFC is determined by several aspects of the system: solar radiation, photosynthetic efficiency of the plant, organic matter allocation from plant to soil, and efficiency of the Microbial Fuel Cell (MFC) [10]. Timmers et al. identified that the P-MFC has a high internal resistance, which limits the power density [14]. In order to increase the power density, internal resistance should be decreased. When calculating the power density as a function of the internal resistance,

$$
P=V_{\max } \times i-\left(i^{2} \times R_{i}\right)
$$

Equation 1 Power density (P) as function of maximum voltage $\left(\mathrm{V}_{\max }=1.1 \mathrm{~V}\right)$, current density $\left(\mathrm{i}, \mathrm{A} / \mathrm{m}^{2}\right)$ and internal resistance $\left(\mathrm{R}_{\mathrm{i}}, \Omega \mathrm{m}^{2}\right)$ in a P-MFC $[15,16]$. Derivation of equation can be found in supporting information.

It shows that current and power densities are very dependent on internal resistance of the system. From Equation 1it can be calculated that the internal resistance needs to be reduced to $0.094 \Omega \mathrm{m}^{2}$ membrane surface area to be able to reach the theoretical power output of $3.2 \mathrm{~W} / \mathrm{m}^{2}$ membrane surface area (Figure 1).
One of the factors influencing internal resistance is the average distance between anode and cathode. The design that was used by Strik et al. [12], Timmers et al. [11] and Helder et al. [9] is a tubular design. In this design anode is tubularly shaped with a membrane at the bottom of the tube. Cathode is situated underneath the anode (Figure 2a). When electrons are homogeneously produced in the anode-compartment, average transport distance for a proton to travel from anode through the membrane to the cathode is relatively long. A long distance from anode to cathode leads to transport losses in the anode. Research by Timmers et al. [11] has shown that internal resistance of the P-MFC, especially transport resistance, is an important limiting factor in the power output of the system. In the flat-plate P-MFC (Figure 2b) anode and cathode are placed next to each other with a membrane vertically in between. This way distance from anode through cathode is smaller and transport resistance will be limited.

The flat-plate system has been described before, but internal resistances of this design were not characterized. In this paper we describe the different partial internal resistances in the flat-plate P-MFC after 320 days runtime of the experiment. Internal resistances were determined at different rooting depths in the P-MFC. To enable this, three separate anodes were used in the system, which were not electronically connected.

\section{Results and discussion}

The plants in both P-MFCs kept growing throughout the experiment, allowing us to acquire data during 350 days on the performance of the P-MFCs with growing plants. During the experiment top anode of the PMFC produced most electricity, the middle part less and the bottom part the least (Figure 3). This was consistent with the root-growth. Most roots were found in the top

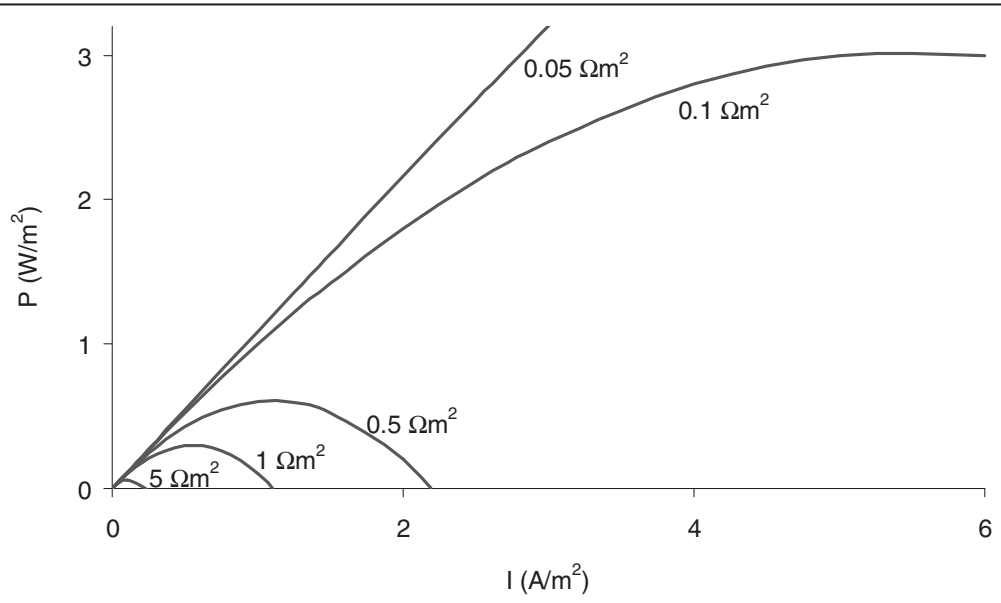

Figure 1 Power density as a function of current density at different internal resistances, which shows that internal resistance should be $<0.094 \Omega \mathrm{m}^{2}$ to achieve a power density of $3.2 \mathrm{~W} / \mathrm{m}^{2}$. 


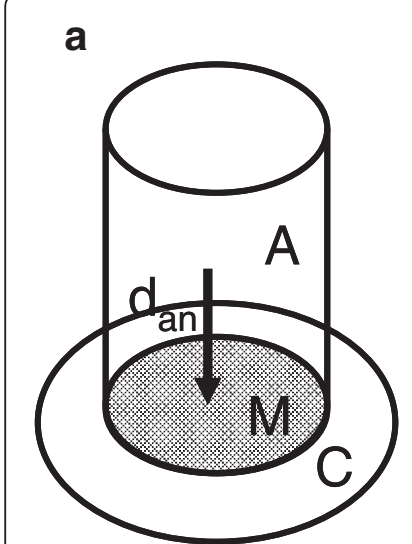

b

Figure 2 Tubular (2a) and flat-plate (2b) design of a Plant Microbial Fuel Cell, in which $\mathrm{A}=$ anode, $\mathrm{C}=$ cathode, $M=$ membrane, $d_{a n}=$ average distance between anode and membrane. Distance between anode and membrane is shorter in flat-plate design than in tubular design.

anode (43.8 and $15.1 \mathrm{~g}$ in P-MFC 1 and 2), less in the middle anode (1.0 and $3.2 \mathrm{~g}$ ) and least in the bottom anode $(<0.1$ and $0.1 \mathrm{~g})$. Electricity production seems linked to root growth, the more roots present in the anode, the more electricity is produced. This is consistent with the idea that the organic matter used for electricity production originates from the roots.

\section{Anodic resistance is the highest partial internal resistance in flat-plate P-MFC}

Partial and total internal resistances were calculated for the three different levels in two P-MFCs (top, middle, bottom) on day 320 of the experiment (Figure 4). In both P-MFCs at all levels and both at low and high current density anodic resistance added substantially to the total internal resistance (Figure 4). It should be noted that we used ferric-cyanide as final electron acceptor in the cathode, thus cathode over-potential would not show in our calculations. Overpotential at the anode is the amount of energy that is lost in the oxidation of organic matter and includes activation energy, microbial energy for maintenance and growth,ohmic losses and concentration losses [16,17]. Concentration losses are determined by the substrate availability at the anodesurface and accumulation of products at the anodesurface $[16,17]$. Substrate availability is determined by the substrate-input and its mass transfer. Substrateinput in the P-MFC is determined by root exudation and dead root turnover [10]. It can therefore be expected that highest substrate-availability is where most roots are. Highest anodic resistance would therefore be expected where least roots are present.

In case of P-MFC 1 this was true; most roots were found in the top part of the system, less in the middle part and least in the bottom part. Anodic resistance of the bottom part of P-MFC 1 (Figure 4a, b) increases with a lower external resistance, while current density does not increase for this level. This is likely due to the fact that hardly any roots were present $(<0.1 \mathrm{~g})$ and so substrate was not available to increase current density. If current density cannot be increased, but external resistance allows more current to flow, overpotential will increase. The same occurred in the middle part of P-MFC 1 , albeit to a lesser extent, and even in the top part of PMFC 1, where most roots were found, anode-resistance increased with a lower external resistance, indicating possible substrate-limitation.

P-MFC 2 shows a different pattern (Figure 4c, d). Top and middle part of P-MFC 2 have shown for the largest part of the runtime of the experiment the same voltage

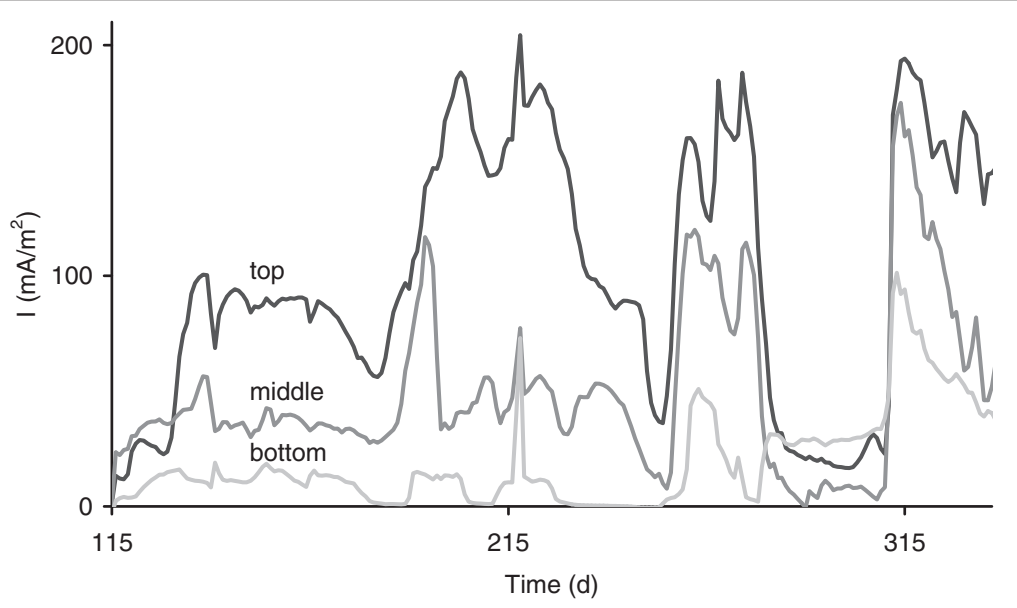

Figure 3 Electricity production $\left(\mathrm{mA} / \mathrm{m}^{2}\right)$ in top, middle and bottom sections of P-MFC 1 during day 115 through 337 in which top section produces most electricity. Fluctuations in power output over time are caused by changes in medium composition as described in Helder et al. 2011 [13]. 

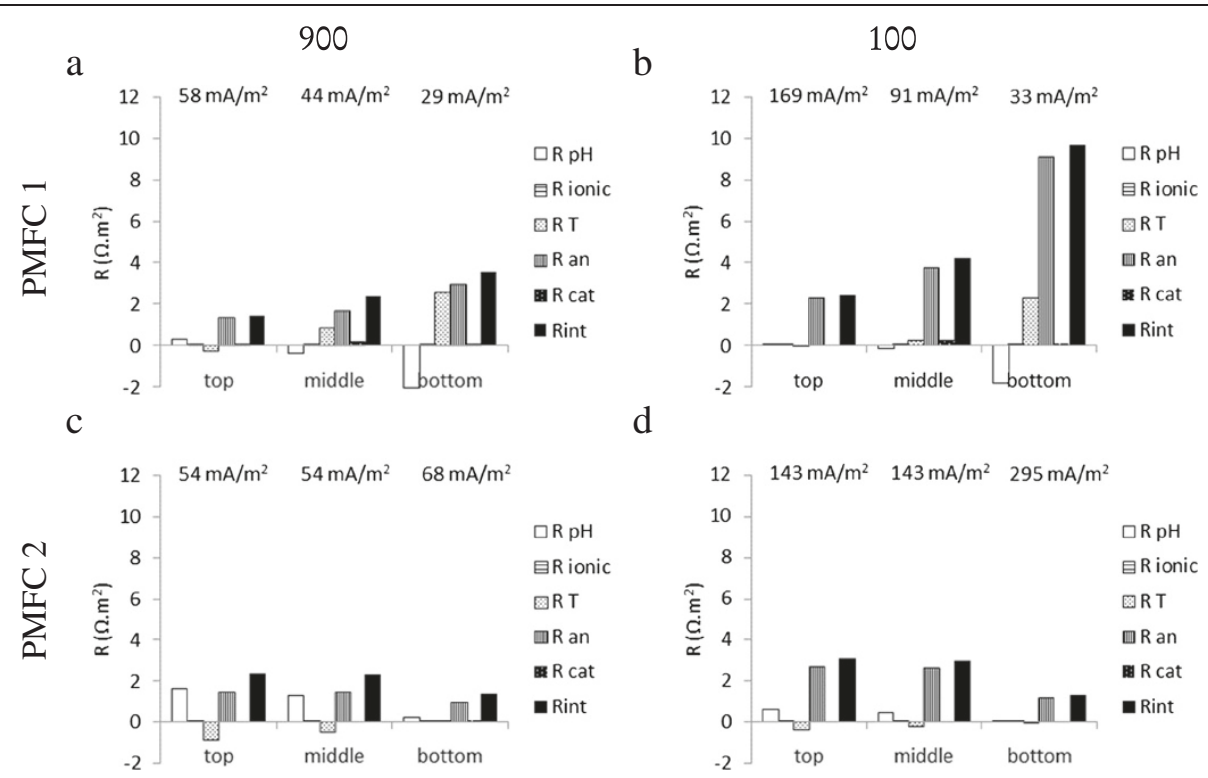

Figure 4 Partial and total internal resistances $\left(\Omega \cdot \mathrm{m}^{2}\right.$ membrane surface area) at three different depths (top, middle, bottom) in two P-MFCs on day 320 of experiment at $900 \Omega$ and $100 \Omega$ external resistance.

and anode and cathode potentials. Likely an electrical connection between top and middle anode of P-MFC 2 existed, so that these two anodes have actually functioned as one. Top and middle level of P-MFC 2 show therefore the same partial and total internal resistance, even though more roots were present in the top part of P-MFC 2 than in the middle part of P-MFC 2. Since electrons could flow freely between the two anodes, substrate limitation at one of them will not directly lead to a higher anode resistance as long as at the other anode substrate is still available. Opposite to the situation in P-MFC 1, the bottom part of P-MFC 2 shows highest current and lowest internal resistance of the three levels in P-MFC 2. Like in P-MFC 1, the bottom part of P-MFC 2 hardly contained any roots. The bottom part of P-MFC 2, however, did contain at least one root-tip. Literature describes that so-called hotspots can occur in the rhizosphere $[18,19]$. A hotspot is a place in the root zone where microbial activity and exudation are enhanced compared to the rest of the rhizosphere [18]. Intensity of turnover processes in these hotspots is at least one order of magnitude higher than in the bulk-soil [18]. Even so, hotspots will likely have occurred in the top and middle anode as well. More research should be done to further explore the hotspot hypothesis and exclude artifacts.

The high anode resistance in our experiment is in contrast with earlier research with the tubular system, which showed a high membrane resistance, which was mainly caused by the transport resistance [11,14]. In our experiment, however, membrane resistance stayed low during polarization (Figure 5), thus transport resistance did not increase. Experimental conditions of Timmers et al. differed on three important aspects from our experiment: 1) design, 2) plant-growth medium and 3) timesteps in the polarization curve.

\section{Influence of design on internal resistance}

It is likely that the design of the system (tubular versus flat-plate) has a large influence on the internal resistance. In our experiment plant-roots were mainly found in the top part of the system, which was consistent with previous experiments $[9,11,12,14]$. This means that in the tubular system the average distance for protons produced in the anode (or other cations like $\mathrm{K}^{+}$or $\mathrm{Na}^{+}$) to travel to the cathode is larger than in the flat-plate system (Figure 2). A larger distance will lead to a higher ionic resistance (Equation 8) and with that to a higher membrane resistance. It was shown in previous research by Timmers et al. $[11,14]$ that membrane resistance was high and increased during polarization curves, which was not the case with the flat-plate system (Figure 5).

Internal resistance in the flat-plate P-MFC was, however, not lower than in the tubular P-MFC (Table 1). Current density was not higher in the flat-plate system P-MFC compared to the tubular P-MFC when normalized to membrane surface area (Table 1). The flat-plate design has, however, advantages over the tubular design. When calculating current and power per $\mathrm{m}^{3}$ it shows that Timmers et al. produced $7.5 \mathrm{~A} / \mathrm{m}^{3}$ and $1.3 \mathrm{~W} / \mathrm{m}^{3}$ whereas we produced $122 \mathrm{~A} / \mathrm{m}^{3}$ and $5.8 \mathrm{~W} / \mathrm{m}^{3}$. Firstly, this leads to the conclusion that materials are more efficiently used in the flat-plate system than in the tubular 


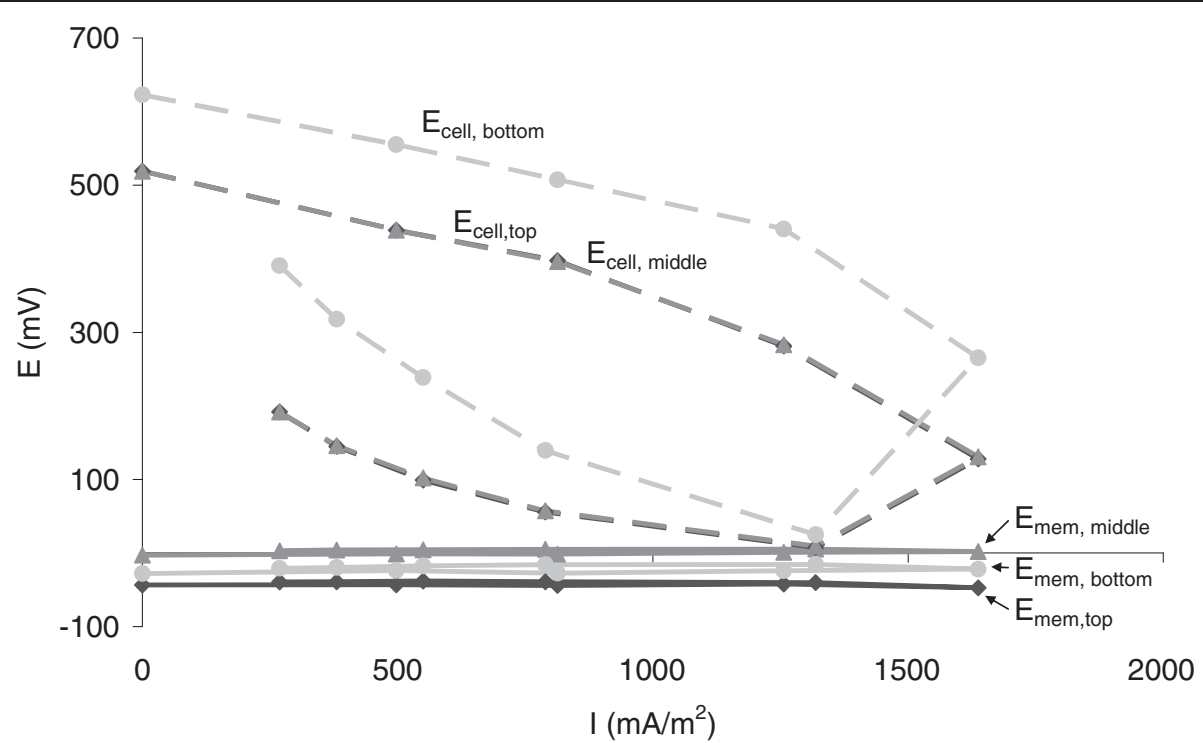

Figure 5 Membrane voltages $\left(E_{\text {mem }}\right)$ and cell voltages $\left(E_{\text {cell }}\right)$ as a function of current density in top, middle and bottom sections of P-MFC 2 during polarization curve on day 320, in which membrane voltages stay low with increasing current, indicating a small membrane resistance.

system, leading to higher outputs on volume base. Secondly, when normalizing current and power density to geographic planting area $1.6 \mathrm{~A} / \mathrm{m}^{2}$ and $0.44 \mathrm{~W} / \mathrm{m}^{2}$ were achieved, which is higher than reported for a tubular PMFC $\left(0.15 \mathrm{~A} / \mathrm{m}^{2}\right.$ and $\left.0.22 \mathrm{~W} / \mathrm{m}^{2}[9,11]\right)$ in a polarization curve with 10 minute time-steps. So with less materials the flat-plate P-MFC harvests more electrons per plant than the tubular P-MFC and is therefore an important step towards optimizing the P-MFC.

Influence of difference in plant-growth medium on internal resistance

In the tubular system a large transport resistance was found, whereas transport resistance in the flat-plate

Table 1 Total internal resistances in $\Omega \cdot \mathrm{m}^{2}$ membrane and $\Omega \cdot \mathrm{m}^{3}$ reactor volume of P-MFC 1 and 2 (flat-plate) and P-MFC (tubular) of Timmers et al. 2012 [14]

\begin{tabular}{|c|c|c|c|c|}
\hline & $\begin{array}{l}\text { Time-step polarization } \\
\text { curve (min) }\end{array}$ & $\begin{array}{l}\text { Current density } \\
\left(\mathrm{mA} / \mathrm{m}^{2}\right)\end{array}$ & $\begin{array}{c}\text { Total internal } \\
\text { resistance }\left(\Omega \mathrm{m}^{2}\right)\end{array}$ & $\begin{array}{l}\text { Total internal } \\
\text { resistance }\left(\Omega \mathrm{m}^{3}\right)\end{array}$ \\
\hline P-MFC 1 top & 10 & 58 & 1.4 & 0.03 \\
\hline P-MFC 1 top & 10 & 169 & 2.4 & 0.05 \\
\hline P-MFC 2 top & 10 & 54 & 2.4 & 0.05 \\
\hline P-MFC 2 top & 10 & 143 & 3.1 & 0.06 \\
\hline P-MFC 1 middle & 10 & 44 & 2.4 & 0.05 \\
\hline P-MFC 1 middle & 10 & 91 & 4.2 & 0.08 \\
\hline P-MFC 2 middle & 10 & 54 & 2.3 & 0.05 \\
\hline P-MFC 2 middle & 10 & 143 & 3.0 & 0.06 \\
\hline P-MFC 1 bottom & 10 & 29 & 3.5 & 0.07 \\
\hline P-MFC 1 bottom & 10 & 33 & 9.7 & 0.19 \\
\hline P-MFC 2 bottom & 10 & 68 & 1.4 & 0.03 \\
\hline P-MFC 2 bottom & 10 & 295 & 1.3 & 0.03 \\
\hline Timmers et al. tubular & 5 & 70 & 0.8 & 0.24 \\
\hline Timmers et al. tubular & 5 & 1800 & 0.2 & 0.06 \\
\hline Timmers et al. Tubular & 60 & 200 & 0.3 & 0.09 \\
\hline Timmers et al. Tubular & 60 & 900 & 0.6 & 0.17 \\
\hline
\end{tabular}

Numbers of Timmers et al. were estimated from figures. 
system is low. It should be noted though, that the plantgrowth medium can influence transport resistance as well. Conductivity was $0.15-0.17{\mathrm{~S} . \mathrm{m}^{-1}}^{-1}$ in the experiment of Timmers et al. and 1.1-1.3 S.m ${ }^{-1}$ in our experiment. Higher conductivity in our experiment will lead to a lower ionic resistance compared to Timmers et al. This would mean, however, that according to Equation 5 transport resistance could be expected to be higher than in the case of Timmers et al. The use of buffer in the experiment of Timmers et al. and the lack of it in our experiment can have an influence on the $\mathrm{pH}$-gradient over the membrane. It is shown in Figure 4 that $\mathrm{pH}-$ resistance in our case can be positive or negative, meaning the $\mathrm{pH}$-gradient from cathode to anode can be either positive or negative (Equation 6). When cathode-pH is higher than anode- $\mathrm{pH}, \mathrm{pH}$-gradient is positive, protons produced in the anode will have to migrate from anode to cathode. Protons migrate from a low $\mathrm{pH}$ to a high $\mathrm{pH}$, so transport is driven by $\mathrm{pH}$-difference. A $\mathrm{pH}$ resistance is present, however, due to the change in electromotive force (EMF), as described by the Nernst equation (Equation 7). When the gradient is negative, however, protons will migrate from cathode to anode and the resistance is reversed to a driving force to produce protons. Based on Equation 5, a positive $\mathrm{pH}-$ resistance will reduce the transport resistance, but a negative $\mathrm{pH}$-resistance will increase the transport resistance, which happens in the middle and bottom level of P-MFC 1 (Figure 5). Compared to the experiment of Timmers et al. transport resistance is lower in our experiment in all cases except bottom part of P-MFC 1 . Thus, even though the difference in plant-growth medium between the experiments of Timmers et al. and ours could influence the internal resistance, it doesn't seem to explain the reduction of transport resistance in the flat-plate system compared to the tubular system.

\section{Influence of time-steps used in polarization curve on internal resistance}

Timmers et al. have shown that the time-steps used to make a polarization curve have a large influence on the internal resistance [14]. The longer the time-steps, the higher the internal resistance, due to an increasing anode resistance caused by proton build-up and an increasing membrane resistance caused by accumulation of cations in the anode [14]. In order to properly compare our results with those of Timmers et al. and understand the mechanisms, it is therefore important to realize that time-steps in the experiment of Timmers et al. (2011) were 5 or 60 minutes [14]. In Timmers et al. (2010) time-steps of polarization are not reported [11]. In our experiment time-steps of 10 minutes were used. Compared to the 5 minute time-step results of Timmers et al., a higher internal resistance could be expected in the flat-plate system, but compared to the 60 minute time-step results, our internal resistance was expected to be lower. Total internal resistance in the flat-plate P-MFC was higher than in the tubular system when normalized to membrane surface area, which cannot be explained from the difference in time-steps (Table 1). When we look to internal resistance when normalized to MFC-volume, however, the picture is different and the flat-plate P-MFC does indeed show a lower internal resistance than the tubular P-MFC in all cases except bottom anode of P-MFC 2 at low external resistance.

\section{Internal resistance in relation to power output of the flat-plate P-MFC}

When comparing the obtained power and current densities of the flat-plate P-MFCs with the expected results based on Equation 1, it shows that only in a few cases measured value approximates theoretical value (Table 2).

Table 2 Expected and measured power densities $\left(P, W / m^{2}\right)$, based on calculated internal resistances $\left(R_{i}, \Omega m^{2}\right)$ and measured current densities $\left(i, A / m^{2}\right.$ )

\begin{tabular}{lcccc}
\hline $\mathbf{R}_{\mathbf{i}}\left(\mathbf{\Omega} \mathbf{m}^{\mathbf{2}}\right)$ & $\mathbf{i}\left(\mathbf{A} / \mathbf{m}^{\mathbf{2}}\right)$ & Expected $\mathbf{P}\left(\mathbf{W} / \mathbf{m}^{2}\right)$ & Measured $\mathbf{P}\left(\mathbf{W} / \mathbf{m}^{2}\right)$ & $\Delta \mathbf{P}\left(\mathbf{W} / \mathbf{m}^{2}\right)$ \\
\hline 1.283 & 0.295 & 0.213 & 0.244 & 0.032 \\
1.380 & 0.069 & 0.069 & 0.013 & -0.056 \\
1.444 & 0.058 & 0.059 & 0.010 & -0.050 \\
2.302 & 0.054 & 0.053 & 0.008 & -0.045 \\
2.354 & 0.054 & 0.053 & 0.008 & -0.044 \\
2.396 & 0.169 & 0.118 & 0.081 & -0.037 \\
2.404 & 0.044 & 0.043 & 0.005 & -0.038 \\
2.982 & 0.145 & 0.097 & 0.059 & -0.038 \\
3.060 & 0.142 & 0.095 & 0.057 & -0.038 \\
3.542 & 0.029 & 0.029 & 0.002 & -0.027 \\
4.169 & 0.091 & 0.066 & 0.023 & -0.042 \\
9.668 & 0.033 & 0.026 & 0.003 & -0.023 \\
\hline
\end{tabular}


This has several reasons. Figure 1 was drawn based on theoretical potentials of anode and cathode and a total theoretical cell voltage of $1.1 \mathrm{~V}$ [20]. This can only be obtained, however, when using oxygen as final electron acceptor in the cathode, whereas we used ferric-cyanide, which has a lower theoretical potential than oxygen. Even so, use of oxygen would not directly lead to higher power outputs, since oxygen-use in the cathode usually leads to high cathode over-potentials due to limited diffusion of oxygen into the electrode and thus oxygen-limitation at the electrode surface. On the anode-side the theoretical potential is probably being overestimated when assuming that it is $-0.5 \mathrm{~V}$ ( $\mathrm{vs} \mathrm{Ag} / \mathrm{AgCl}$ ), which is the theoretical potential of acetate oxidation under MFC-conditions [17]. Since substrate in the P-MFC originates from the plant, it is a complex mixture of several different organic compounds with different theoretical potentials [10]. Moreover, oxygen is being transported into the anode by the plant-roots, limiting the number of electrons available for electricity production, and, at low substrate concentrations leading to a mixed anode potential. This mixed anode potential will be higher than the assumed $-0.5 \mathrm{~V}$. Furthermore, the polarization curve shows that the internal resistance of the system is not linear. The theoretical internal resistance and resulting current and power output based on Equation 1 is only valid when internal resistance of the system is linear [21]. It is therefore not surprising that measured current and power densities don't match with the theoretical values.

\section{Conclusions}

The flat-plate P-MFC design resulted in a lower transport and membrane resistance than the previously used tubular P-MFC. It did, however, not result in a lower total internal resistance normalized to membrane surface area. Total internal resistance of the flat-plate P-MFC is at best comparable to total internal resistance of the tubular P-MFC, only differently distributed over several partial internal resistances. In the flat-plate P-MFC the anodic resistance is highest, when using a chemical cathode, due to substrate limitation or mass transfer limitation. To overcome the problem of substrate limitation, either the plant should exudate more, exudates should be converted into electricity more efficiently or other rhizodeposits, like dead root material should be used. Possibly, when rhizosphere is fully mature, more dead root material is available, which will probably lead to higher substrate availability in the P-MFC. Higher exudation rates might be achieved by adapting the plantgrowth medium to stimulate exudation [22]. For future research it would be interesting to further reduce anode height, since the middle and bottom level anodes generally generated less electricity (Figure 3 ) than the top one and most roots were found in the top anode.

\section{Materials and methods}

\section{Set-up and operation}

Two flat-plate P-MFCs were run for 703 days. The anode compartment had a total volume of $648 \mathrm{ml}$ $(18 \times 18 \times 2 \mathrm{~cm})$. The anode consisted of three sections of graphite felt of $5 \mathrm{~cm}$ height (Grade WDF, $6 \mathrm{~mm}$, National Specialty Products Carbon and Graphite Felt, Taiwan), which were physically separated (Figure 6a) A gold wire was woven through the graphite felt of each section to serve as current collector. Three plants of Spartina anglica (grown in a greenhouse from offshoot of Timmers et al. (2010)) were planted in each P-MFC. The anode compartment was separated from the cathode

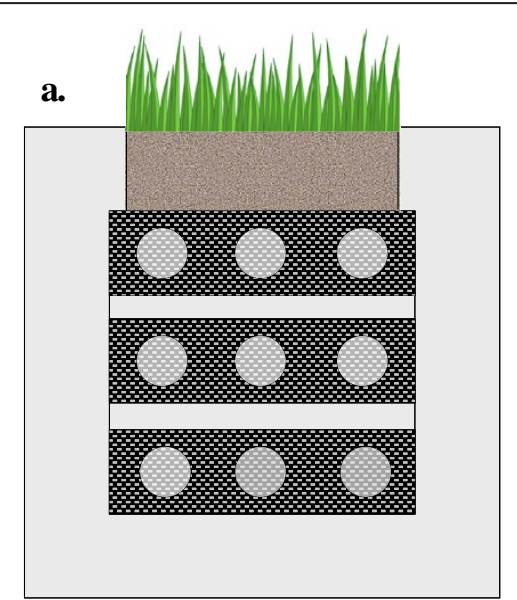

b.

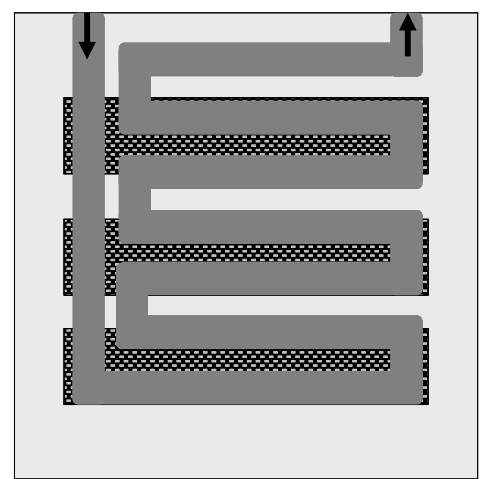

Figure 6 Anode (6a) and cathode (6b) schematic overview of a flat-plate Plant Microbial Fuel Cell. In anode and cathode top, middle and bottom sections are shown; in anode sample-points are shown; and in cathode the flow-through channel is shown. 
compartment by a cation exchange membrane (CEM) (Fumatec, Frankfurt, Germany).

The cathode consisted of three sections of graphite felt of $5 \mathrm{~cm}$ height, (Grade WDF, $2.8 \mathrm{~mm}$, National Specialty Products Carbon and Graphite Felt, Taiwan), each corresponding with an anode section (Figure 6b). The cathode compartment consisted of two flow-through modules with the graphite felt in between. A gold wire was woven through the graphite felt of each section to serve as current collector. From day 70 ferric cyanide $\left(\mathrm{K}_{3} \mathrm{Fe}(\mathrm{CN})_{6}\right.$, $50 \mathrm{mM}$ ) was used as catholyte to stabilize cathodepotential and be able to study anode-potential. Ferric cyanide was replenished whenever cathode-potential dropped below $+200 \mathrm{mV}$ (against $\mathrm{Ag} / \mathrm{AgCl}$ reference electrode).

From day 1 through day 116 top, middle and bottom sections of the anode were electronically connected, thus behaving as one anode. During this period external load between anode and cathode was $300 \Omega$. From day 117 anode-sections were electronically disconnected. The three anode-sections all were connected to their corresponding cathode over an external load of $900 \Omega$.

Different plant-growth media were used during the runtime of the experiment, as described in Helder et al. 2011 for P-MFC 3 and 4 [13]. At determination of the internal resistances at day 320 a nitrate-less, ammonium-rich medium was used with composition as in Table 3.

Anode and cathode potential were measured with $\mathrm{Ag} / \mathrm{AgCl}$-reference electrodes (3 M KCl, + $205 \mathrm{mV}$ versus SHE, ProSenseQis). Data was logged every 60 seconds with Fieldpoint (Module S, National Instruments) and collected with Labview (National Instruments Software). To test maximum power density polarization curves were made simultaneously for each section. These were made by disconnecting anode and cathode for 30 minutes to reach open cell voltage $(\mathrm{OCV})$ and subsequently connecting anode and cathode over an external load of 900, 500, 250, $100,10,100,250,500$ and $900 \Omega$, for 10 minutes each. At day 320 anode was sampled at 9 samplepoints, which were evenly distributed over the three anode-sections, so three sample-points in each anodesection. Samples of $1 \mathrm{ml}$ each were measured for conductivity (ProLine Plus Qis, ProSense BV, Oosterhout, The Netherlands) and pH (691 pH-meter, Metrohm, Herisau, Switzerland).

The set-ups were placed in a climate chamber (Microclima 1750 Snijders) with an average light intensity of $596 \pm 161 \mu$ mole $\mathrm{m}^{-2} \mathrm{~s}^{-1}$, measured at the top of the set-ups witha light intensity meter (Photodyne 44XLA). The climate chamber was controlled at $25^{\circ} \mathrm{C}$ with $75 \%$ humidityand a day-night regime of 14:10 hours was used.
Table 3 Concentrations of macronutrients, micronutrients, and added salts in demineralized water as composition of the plant-growth medium

\begin{tabular}{lc}
\hline & Concentration \\
\hline Macronutrients & mg/L \\
$\mathrm{NH}_{4} \mathrm{HCO}_{3}$ & 553.5 \\
$\mathrm{CaCl}_{2}$ & 222 \\
$\mathrm{NH}_{4} \mathrm{H}_{2} \mathrm{PO}_{4}$ & 115.1 \\
$\mathrm{MgSO}_{4} \cdot 7 \mathrm{H}_{2} \mathrm{O}$ & 123.245 \\
$\mathrm{Na}_{2} \mathrm{SiO}_{3} \cdot 9 \mathrm{H}_{2} \mathrm{O}$ & 142.1 \\
$\mathrm{KCl}$ & 223.68 \\
$\mathrm{Micronutrients}$ & $\mathbf{m g} / \mathbf{L}$ \\
$\mathrm{KCl}$ & 1.864 \\
$\mathrm{H}_{3} \mathrm{BO}_{3}$ & 0.773 \\
$\mathrm{MnSO}_{4} \cdot \mathrm{H}_{2} \mathrm{O}$ & 0.169 \\
$\mathrm{ZnSO}_{4} \cdot 7 \mathrm{H}_{2} \mathrm{O}$ & 0.288 \\
$\mathrm{CuSO}_{4} \cdot 5 \mathrm{H}_{2} \mathrm{O}$ & 0.062 \\
$\mathrm{H}_{2} \mathrm{MoO}_{4}(85 \% \mathrm{MoO})$ & 0.04 \\
$\mathrm{CoCl}_{2} \cdot 6 \mathrm{H}_{2} \mathrm{O}$ & 1 \\
$\mathrm{Na}_{2} \mathrm{SeO}_{3}$ & 0.05 \\
$\mathrm{C}_{14} \mathrm{H}_{18} \mathrm{~N}_{3} \mathrm{O}_{10} \mathrm{FeHNa}$ & 5 \\
$\mathrm{NiSO}_{4} \cdot 6 \mathrm{H}_{2} \mathrm{O}$ & 0.03 \\
$\mathrm{Salt}$ & $\mathbf{g} / \mathbf{L}$ \\
$\mathrm{NaCl}$ & 10 \\
\hline
\end{tabular}

After 703 days the set-ups were taken apart and rootweight was measured for the three anode-sections per PMFC.

\section{Calculations}

Internal resistance of the P-MFC can be split in several partial internal resistances as in [23]:

$$
R_{\text {int }}=R_{a n}+R_{c a t}+R_{T}
$$

Equation 2 Internal resistance in a P-MFC $\left(\Omega . \mathrm{m}^{2}\right)$, in which $R_{a n}=$ anodic resistance $\left(\Omega . \mathrm{m}^{2}\right), R_{\text {cat }}=$ cathodic resistance $\left(\Omega \cdot \mathrm{m}^{2}\right), R_{T}=$ transport resistance $\left(\Omega \cdot \mathrm{m}^{2}\right)$.

Anodic resistance can be calculated from the overpotential of the anode according to [14]:

$$
R_{a n}=\frac{\left(E_{a n}-E_{a n}^{0}\right)}{i}
$$

Equation 3 Anodic resistance in a P-MFC $\left(\Omega . \mathrm{m}^{2}\right)$, in which $E_{a n}^{0}=$ theoretical anode potential $(\mathrm{V}), E_{a n}=$ measured anode potential at a certain external resistance $(\mathrm{V}), i=$ current density $\left(\mathrm{A} / \mathrm{m}^{2}\right)$.

Since the theoretical anode potential in the P-MFC is based on a mixed potential [21] and concentrations of different exudates are unknown, it is assumed that 
theoretical anode potential equals open cell potential $\left(\mathrm{E}_{\mathrm{an}, \mathrm{OCP}}\right)$.

Cathodic resistance can be calculated from the cathode over-potential according to [14]:

$$
R_{c a t}=\frac{\left(E_{c a t}^{0}-E_{c a t}\right)}{i}
$$

Equation 4. Cathodic resistance in a P-MFC $\left(\Omega \cdot \mathrm{m}^{2}\right)$, in which $E_{a n}^{0}=$ theoretical cathode potential at $50 \mathrm{mM}$ ferric cyanide solution $(\mathrm{V}), E_{c a t}=$ measured cathode potential at a certain external resistance $(\mathrm{V}), i=$ current density $\left(\mathrm{A} / \mathrm{m}^{2}\right)$

Transport losses of the system were calculated as in Timmers et al. (2010) [11] and can be calculated as [11,23]:

$$
E_{T}=E_{\text {mem }}-E_{\Delta p H}-E_{\text {ionic }}
$$

Equation 5 Transport loss in a P-MFC (V), in which; $\mathrm{E}_{\mathrm{mem}}=$ measured potential over the membrane $(\mathrm{V})$, $\mathrm{E}_{\Delta \mathrm{pH}}=\mathrm{pH}$ gradient loss $(\mathrm{V}), \mathrm{E}_{\text {ionic }}=$ ionic loss $(\mathrm{V})$.

When dividing this equation by current, transport resistance can be calculated. The potential over the membrane is measured as the difference between the reference electrode in the anode and the reference electrode in the cathode. The $\mathrm{pH}$ resistance is calculated as [11]:

$$
R_{\Delta p H}=\frac{\left(\frac{R T}{F} \ln \left(10^{\left(p H_{c a t h}-p H_{a n}\right)}\right)\right)}{i}
$$

Equation $6 \mathrm{pH}$ resistance in an MFC, in which $\mathrm{pH}_{\text {cath }}=$ cathode $\mathrm{pH}, \mathrm{pH}_{\mathrm{an}}=$ anode $\mathrm{pH}$, and $\mathrm{i}=$ current density per membrane area.

Equation for $\mathrm{pH}$ resistance is derived from the Nernst equation:

$$
E_{O C P, a n}=E_{a n}^{0}-\frac{R T}{n F} \ln \frac{\left[\mathrm{CH}_{3} \mathrm{COO}^{-}\right]}{\left[\mathrm{H}^{+}\right]^{9}\left[\mathrm{HCO}_{3}^{-}\right]^{2}}
$$

Equation 7 Nernst-equation, in which $E_{a n}^{0}$ is the standard potential $(\mathrm{V}), \mathrm{R}$ is the universal gas constant (8.314 J mol-1 K-1), $\mathrm{T}$ is the temperature $(\mathrm{K}), \mathrm{n}$ is the number of electrons involved in the reaction (-), $\mathrm{F}$ is Faraday's constant $\left(96485 \mathrm{C}\right.$ mol-1), $\left[\mathrm{CH}_{3} \mathrm{COO}^{-}\right]$is the acetate activity (mol L-1), $\left[\mathrm{H}^{+}\right]$is the proton activity (mol L-1), and $\left[\mathrm{HCO}_{3}^{-}\right]$is the bicarbonate activity (mol L-1).

This equation shows that one $\mathrm{pH}$-unit difference will lead to a change in anode potential of $59 \mathrm{mV}$.

Ionic resistance is calculated as $[11,23]$ :

$$
R_{\text {ionic }}=\left(\frac{d_{a n}}{\sigma_{a n}}\right)
$$

Equation 8 Ionic resistance in the anode of an MFC, in which $d_{a n}=$ average distance between point of proton production and membrane, and $\sigma_{\mathrm{an}}=$ conductivity of anolyte.

Power densities are expressed per geometric planting area because it gives insight in the possibility to use this technology for large scale electricity production.

\section{Abbreviations}

P-MFC: Plant-Microbial Fuel Cell the technology to produce electricity with living plants; MFC: Microbial Fuel Cell bio-electrochemical system to produce electricity from organic matter; EMF: Electromotive force driving force for electrons; CEM: Cation exchange membrane selective membrane for cations; OCV: Open Cell Voltage voltage at open circuit (zero current).

\section{Competing interests}

Two of the authors of the manuscript, Marjolein Helder and David Strik, founded a spin-off company from Wageningen University to further develop the Plant-Microbial Fuel Cell into products. The company does not generate any income and has no interest in the conducted research. Results presented in this paper were not in any way influenced by the existence of the spin-off company.

\section{Authors' contributions}

$\mathrm{MH}$ co-designed and co-executed the experiment, analyzed data and drafted the paper, DS co-designed and co-executed the experiment, critically assessed data and critically reviewed the paper, $\mathrm{HH}$ invented the technology, co-designed the experiment, critically assessed data and critically reviewed the paper, CB designed the research project, critically assessed data and critically reviewed the paper. All authors read and approved the final manuscript.

\section{Acknowledgements}

We would like to thank Ruud Timmers for his input on the flat-plate design and help with the practical work. We would like to thank the Plantpower consortium for thinking along with us on the design of the flat-plate system and the interpretation of the obtained results. The research leading to these results has received funding from the European Community's Seventh Framework Programme FP7/2007-2013 under grant agreement n²26532.

\section{Author details}

${ }^{1}$ Wageningen University - Sub-department of environmental technology, PO box 17, Wageningen 6700 AA, The Netherlands. ${ }^{2}$ Wetsus- Centre of excellence for sustainable water technology, Agora 1, Leeuwarden, The Netherlands.

Received: 12 June 2012 Accepted: 24 July 2012

Published: 21 September 2012

\section{References}

1. Sheffield J: World population growth and the role of annual energy use per capita. Technol Forecast Soc Change 1998, 59:55-87.

2. Asif M, Muneer T: Energy supply, its demand and security issues for developed and emerging economies. Renew Sustain Energy Rev 2007 11:1388-1413.

3. Hill J, Nelson E, Tilman D, Polasky S, Tiffany D: Environmental, economic, and energetic costs and benefits of biodiesel and ethanol biofuels. Proc Natl Acad Sci USA 2006, 103:11206-11210.

4. Fargione J, Hill J, Tilman D, Polasky S, Hawthorne P: Land clearing and the biofuel carbon debt. Science 2008, 319:1235-1238.

5. Huesemann MH: Can advances in science and technology prevent global warming? A critical review of limitations and challenges. Mitig Adapt Strat Glob Chang 2006, 11:539-577.

6. Kaku N, Yonezawa N, Kodama Y, Watanabe K: Plant/microbe cooperation for electricity generation in a rice paddy field. Appl Microbiol Biotechnol 2008, 79:43-49.

7. De Schamphelaire L, Van Den Bossche L, Hai SD, Hofte M, Boon N, Rabaey K, Verstraete W: Microbial fuel cells generating electricity from rhizodeposits of rice plants. Environ Sci Technol 2008, 42:3053-3058.

8. Strik DPBTB, Hamelers HVM, Snel JFH, Buisman CJN: Green electricity production with living plants and bacteria in a fuel cell. Int J Energ Res 2008, 32:870-876. 
9. Helder M, Strik DPBTB, Hamelers HVM, Kuhn AJ, Blok C, Buisman CJN: Concurrent bio-electricity and biomass production in three PlantMicrobial Fuel Cells using Spartina anglica, Arundinella anomala and Arundo donax. Bioresour Technol 2010, 101:3541-3547.

10. Strik DPBTB, Timmers RA, Helder M, Steinbusch KJ, Hamelers HVM, Buisman CJN: Microbial solar cells: applying photosynthetic and electrochemically active organisms. Trends Biotechnol 2011, 29:41-49.

11. Timmers RA, Strik DPBTB, Hamelers HVM, Buisman CJN: Long-term performance of a plant microbial fuel cell with Spartina anglica. Appl Microbiol Biotechnol 2010, 86:973-981.

12. Strik DPBTB, Hamelers HVM, Snel JFH, Buisman CJN: Green electricity production with living plants and bacteria in a fuel cell. Int J Energ Res 2008, 10.1002

13. Helder M, Strik DPBTB, Hamelers HVM, Kuijken RCP, Buisman CJN: New plant-growth medium for increased power output of the Plant-Microbial Fuel Cell. Bioresource Technology 2012, 104:417-423.

14. Timmers RA, Strik DPBTB, Hamelers HVM, Buisman CJN: Characterization of the internal resistance of a plant microbial fuel cell. Electrochimica Acta 2012, article in press.

15. Logan BE, Hamelers B, Rozendal R, Schröder U, Keller J, Freguia S, Aelterman P, Verstraete W, Rabaey K: Microbial fuel cells: methodology and technology. Environ Sci Technol 2006, 40:5181-5192.

16. Fan $Y$, Sharbrough E, Liu H: Quantification of the internal resistance distribution of microbial fuel cells. Environ Sci Technol 2008, 42:8101-8107.

17. Hamelers HVM, Ter Heijne A, Sleutels THJA, Jeremiasse AW, Strik DPBTB, Buisman CJN: New applications and performance of bioelectrochemical systems. Appl Microbiol Biotechnol 2010, 85:1673-1685.

18. Kuzyakov Y: Priming effects: interactions between living and dead organic matter. Soil Biol Biochem 2010, 42:1363-1371.

19. Pausch J, Kuzyakov Y: Photoassimilate allocation and dynamics of hotspots in roots visualized by $14 \mathrm{C}$ phosphor imaging. J Plant Nutr Soil Sci 2011, 174:12-19.

20. Rozendal RA, Hamelers HVM, Rabaey K, Keller J, Buisman CJN: Towards practical implementation of bioelectrochemical wastewater treatment. Trends Biotechnol 2008, 26:450-459.

21. Harnisch F, Schröder U: From MFC to MXC: Chemical and biological cathodes and their potential for microbial bioelectrochemical systems. Chem Soc Rev 2010, 39:4433-4448.

22. Blossfeld S, Perriquey J, Sterckeman T, Morel JL, Lösch R: Rhizosphere pH dynamics in trace-metal-contaminated soils, monitored with planar $\mathrm{pH}$ optodes. Plant Soil 2010, 330:173-184.

23. Sleutels THJA, Hamelers HVM, Rozendal RA, Buisman CJN: Ion transport resistance in microbial electrolysis cells with anion and cation exchange membranes. Int J Hydrogen Energ 2009, 34:3612-3620.

doi:10.1186/1754-6834-5-70

Cite this article as: Helder et al:: The flat-plate plant-microbial fuel cell: the effect of a new design on internal resistances. Biotechnology for Biofuels 2012 5:70.

\section{Submit your next manuscript to BioMed Central and take full advantage of:}

- Convenient online submission

- Thorough peer review

- No space constraints or color figure charges

- Immediate publication on acceptance

- Inclusion in PubMed, CAS, Scopus and Google Scholar

- Research which is freely available for redistribution

Submit your manuscript at www.biomedcentral.com/submit
C Biomed Central 